\section{Oksidativt stress hemmer metastaser}

\author{
Reaktive oksygenderivater kan \\ hemme metastasering ved malignt \\ melanom.
}

Oksygenradikaler kan skade DNA og dermed fremme kreftdanning. En ny studie viser at de også kan påvirke kreftceller i blodsirkulasjonen slik at det dannes færre metastaser (1).

Ikke alle kreftceller som kommer over $i$ blodet fra en primærtumor, danner metastaser. Årsaken til dette er ukjent. I studien ble kreftceller fra malignt melanom, med eller uten metastaser, injisert subkutant og intravenøst i immundefekte mus. Mange av cellene dannet subkutane svulster, men langt færre metastaserte via blodet. Spesielt gjaldt det melanomer som ikke hadde metastasert hos pasientene. Melanomceller i blod, men ikke de subkutane, ble spontant utsatt for oksidativt stress i musene. Melanomceller fra pasienter med metastaser viste reversible metabolske forandringer som økte evnen til å motstå eksposisjon for reaktive oksygenderivater. Antioksidanter viste seg å fremme metastasering uten å affisere tumorveksten subkutant.

- Tidligere trodde man at reaktive oksygenderivater var skadelige biprodukter, men nyere forskning har vist at de også er viktige signalmolekyler, blant annet for apoptose, sier professor Rune Blomhoff ved Institutt for medisinske basalfag, Universitetet i Oslo. - Cellenes antioksidantforsvar kan normalt motvirke høye, skadelige nivåer av reaktive oksygenderivater uten å hindre funksjonen som signalmolekyl. Dette er snakk om balanse - ikke for mye og ikke for lite som ellers i naturen. Denne studien viser at mye reaktive oksygenderivater begrenser metastasering og at antioksidanter øker metastasering. Andre studier har vist at høyt inntak av antioksidanter i form av kosttilskudd kan fremme kreftutvikling og kreftprogrediering. Mekanismen for dette kan være redusert evne til apoptose og økt evne til metastasering. Et balansert inntak av bær, frukt og grønnsaker med antioksidanter vil imidlertid ikke ha slike uønskede effekter, sier Blomhoff.

\section{Haakon B. Benestad}

Universitetet i Oslo

\footnotetext{
Litteratur

1. Piskounova E, Agathocleous M, Murphy MM et al. Oxidative stress inhibits distant metastasis by human melanoma cells. Nature 2015; 527 : $186-91$
}

\title{
Reaktivering av malaria
}

\author{
Tilbakefall av malariasykdom kan skyldes reaktivering av parasitter \\ fra en tidligere infeksjon. Parasittene har holdt seg i leveren siden da.
}

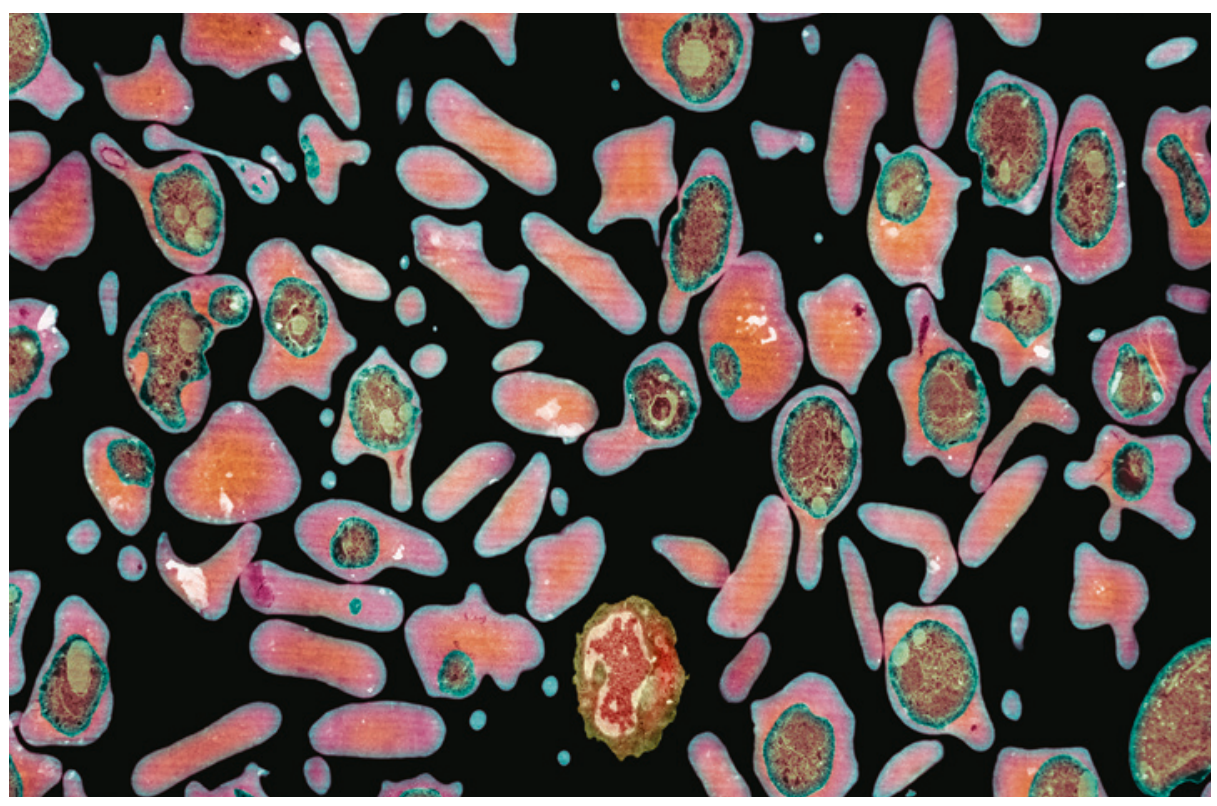

Transmisjonselektronmikrografi av røde blodceller infisert av malaria. Foto: Science Photo Library

Det er identifisert fem malariaarter som gir infeksjoner hos mennesker. To av disse artene, Plasmodium vivax og Plasmodium ovale, skiller seg ut ved at de i et utviklingsstadium omtalt som hypnozoittstadiet infiserer leveren, der de kan hvile i lengre tid før de igjen omdannes og på nytt infiserer blodet. Mange malariamedisiner virker ikke på parasitter i hypnozoittstadiet. Mennesker som er blitt behandlet for infeksjon med P. vivax eller $P$. ovale, kan derfor få tilbakefall av sykdommen uten å være smittet på ny.

I en ny studie fra Papua Ny-Guinea ønsket man å vurdere i hvilken grad tilbakefall bidrar til sykdomsbyrden ved infeksjoner med $P$. vivax og $P$. ovale (1). Studien omfattet 524 barn i alderen 5-10 år som ble randomisert til behandling med malariamedisiner som kun virker på blodstadiet av malariaparasittene (klorokin og artemeter-lumefantrin), sammen med enten placebo eller primakin, som virker på hypnozoitter.

Hos barna som hadde fått primakin, var risikoen for ny infeksjon med $P$. vivax og $P$. ovale i blodet innen åtte måneder redusert med henholdsvis $82 \%$ og $69 \%$ (hasardratio hhv. 0,18 og 0,31). Resultatene tyder på at fire av fem infeksjoner med P. vivax egentlig er tilbakefall av en tidligere infeksjon og at minst tre av fem infeksjoner med $P$. ovale er tilbakefall. Forskerne anbefaler at legemidler som virker på hypnozoittstadiet inkluderes i kampanjer mot disse malariaformene, for at man skal få redusert forekomsten av sykdommen.

\section{Kristoffer Brodwall}

kristoffer.brodwall@gmail.com

Institutt for global helse og samfunnsmedisin Universitetet i Bergen

\section{Litteratur \\ . Robinson LJ, Wampfler R, Betuela I et al. Strate- gies for Understanding and Reducing the Plas- modium vivax and Plasmodium ovale Hypnozoite Reservoir in Papua New Guinean Children: A Ran- domised Placebo-Controlled Trial and Mathemati- cal Model. PLoS Med 2015; 12: e1001891.}

